\title{
A Bibliometric Analysis of Neuromarketing: Current Status, Development and Future Directions
}

\author{
Ahmed H. Alsharif, Nor Zafir Md Salleh, Rohaizat Baharun, Yahia H. Alsharif, \\ Hassan Abuhassna
}

To Link this Article: http://dx.doi.org/10.6007/IJARAFMS/v11-i3/11673 DOI:10.6007/IJARAFMS/v11-i3/11673

Received: 19 July 2021, Revised: 24 August 2021, Accepted: 08 September 2021

Published Online: 27 September 2021

In-Text Citation: (Alsharif et al., 2021)

To Cite this Article: Alsharif, A. H., Salleh, N. Z. M., Baharun, R., Alsharif, Y. H., \& Abuhassna, H. (2021). A Bibliometric Analysis of Neuromarketing: Current Status, Development, and Future Directions. International Journal of Academic Research in Accounting Finance and Management Sciences, 11(3), 828-847.

Copyright: (c) 2021 The Author(s)

Published by Human Resource Management Academic Research Society (www.hrmars.com) This article is published under the Creative Commons Attribution (CC BY 4.0) license. Anyone may reproduce, distribute, translate and create derivative works of this article (for both commercial and non-commercial purposes), subject to full attribution to the original publication and authors. The full terms of this license may be seen at: http://creativecommons.org/licences/by/4.0/legalcode

Vol. 11, No. 3, 2021, Pg. 828 - 847

Full Terms \& Conditions of access and use can be found at http://hrmars.com/index.php/pages/detail/publication-ethics 


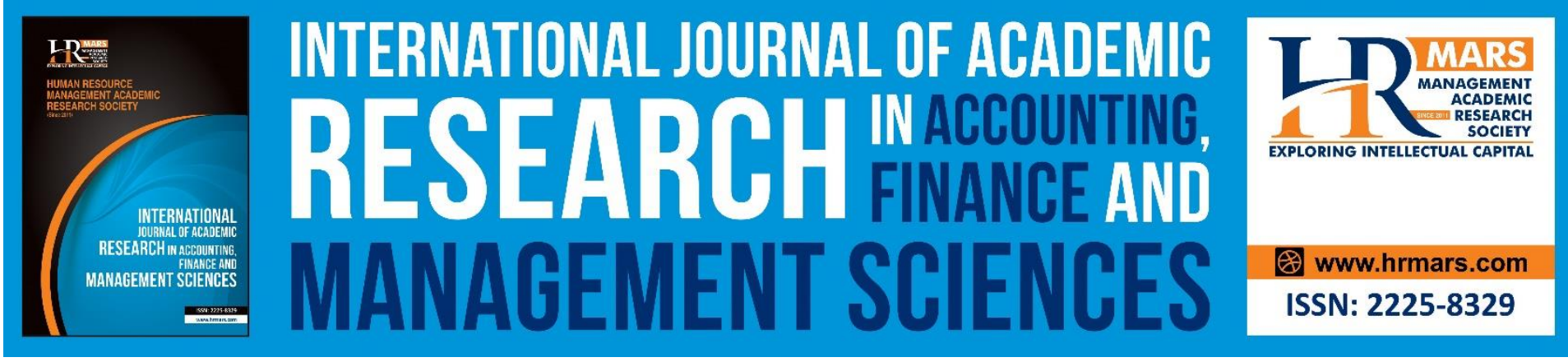

\title{
A Bibliometric Analysis of Neuromarketing: Current Status, Development and Future Directions
}

\author{
Ahmed H. Alsharif ${ }^{1}$, Nor Zafir Md Salleh ${ }^{1}$, Rohaizat Baharun ${ }^{1}$, \\ Yahia H. Alsharif ${ }^{2}$, Hassan Abuhassna ${ }^{3}$ \\ ${ }^{1}$ Azman Hashim International Business School, Universiti Teknologi Malaysia, 81310 Skudai, \\ Johor, Malaysia, ${ }^{2}$ Faculty of Medicine, Islamic University of Gaza, Gaza, Palestine, ${ }^{3}$ Faculty of \\ Social Sciences \& Humanities, Universiti Teknologi Malaysia, 81310 Skudai, Johor, Malaysia.
}

\begin{abstract}
The growth interesting in discovering the consumers' behaviours, emotional and cognitive processes in marketing research have led to an increasing number of publications. This paper aims to evaluate the global research trends in neuromarketing based on the most productive journals, countries, institutions, authors, the number of documents and citations. This paper was structured based on the Preferred Reporting Items for Systematic Reviews and MetaAnalyses (PRISMA) framework to select all relevant documents for this study. A total of 143 papers have been extracted from the Scopus database. The findings revealed that Spain is the leading country with 27 publications, and the most productive institution was Universidad Complutense de Madrid with nine documents. In addition, Babiloni F. is the most prolific author with four publications and 143 citations. Interestingly, although Frontiers in Psychology is the most productive journal with 17 publications, the Journal of Economic Psychology has the highest average citation per item. Keywords and citation analysis are highly significant to know the most impactful documents and words in neuromarketing. Ariely and Berns (2010) have published the most cited paper with 426 citations. We believe that our study will provide a comprehensive overview of global trends in the neuromarketing domain.
\end{abstract}

Keywords: Bibliometric Analysis, Prisma, Neuromarketing, Consumer Neuroscience, Scopus Database

\section{Introduction}

Over the years, marketers and advertisers have been using qualitative approaches (i.e., interviews, focus groups) and quantitative methods (i.e., questionnaires) to study consumers' behaviour (i.e., purchase behaviour) (Alsharif et al., 2021c). In the last decade, business and marketing research had an increasing interest in using neuroscientific methods such as functional magnetic resonance imaging ( $\mathrm{fMRI}$ ) to explore what is in consumers' minds and to predict the purchase decisions of consumers toward marketing practices (Alsharif et al., 2021d; Cherubino et al., 2019). The interest in using neuroscientific methods has led to a new 
MANAGEMENT SCIENCES

Vol. 11, No. 3, 2021, E-ISSN: 2225-8329 @ 2021 HRMARS

field known as "neuromarketing" (Alsharif et al., 2021b; Stanton et al., 2017). Smidts (2002) is the first researcher who has coined the term "neuromarketing" in 2002, and he defined it as the application of neuroscience tools in the business field (Alsharif et al., 2020b). Venkatraman et al (2015) described it as the commercial application of consumer neuroscience. Therefore, marketing and business research have blossomed and expanded in recent years by using several methods such as neuroimaging and physiological tools to pinpoint the consumers' behaviours (i.e., purchase decisions) and the neural correlates of emotional processes (Alsharif et al., 2021a, 2021c) and cognitive processes toward marketing stimuli (e.g., advertising, brands) . Therefore, the combination of traditional marketing and neuromarketing methods can be provided with a piece of valuable information about consumers' behaviour (i.e., conscious and unconscious reactions) (Alsharif et al., 2021e).

Admittedly, methods and tools are highly significant in neuromarketing research. Therefore, tools used in neuromarketing research have been divided into two clusters: (i) neurophysiological tools such as functional magnetic resonance imaging (fMRI), electroencephalography (EEG), magnetoencephalography (MEG), positron emission tomography (PET), and transcranial magnetic stimulation (TMS); and (ii) Physiological tools such as galvanic skin response (GSR), eye-tracking (ET), implicit association test electromyography (EMG), and electrocardiogram (ECG) (Isabella et al., 2015). Neuroimaging/neurophysiological tools such as EEG and fMRI are the most favourable/popular tools among researchers (Alsharif et al., 2021b; Harris et al., 2018).

Hence, to dig deeper into the neuromarketing domain. Based on the aforementioned literature, this study aims to provide comprehensive information about global trends of neuromarketing research in the last decade, such as the most productive authors, countries, academic institutions, journals, the number of articles and citations to be considered in marketing studies, besides, the citation trends and co-citation network between references. This study differs from other review papers relevant to neuromarketing in terms of discussing the global trends of neuromarketing research. To this end, this review paper attempts to incorporate as many trends as possible. This study investigates the global trends profoundly to accomplish an accurate, concrete, and concise conclusion. The main contributions of the current bibliometric survey are summarised below:

- Present a descriptive analysis of selected documents such as annual and cumulative publications and productive journals from 2008- August 2021.

- Provide comprehensive information about the recent global trends in the neuromarketing/consumer neuroscience domain.

- Provide new references and directions to new researchers in the neuromarketing field.

The organisation of the recent paper, as follows: Section 2 provides the materials and methods that have been used in this paper. Section 3 presents the descriptive and bibliometrics analysis of the selected documents. Section 4 discuss the findings of the recent paper. Section 5 presents the conclusions, limitations, and future trends in neuromarketing.

\section{Materials and Methods}

The researchers used a bibliometric analysis to simplify the global trends in neuromarketing according to the outputs of publications such as the most/top productive (e.g., countries, academic institutions, authors, journals), the number of publications and citations to evaluate the blossoming in the neuromarketing and consumer neuroscience field 
MANAGEMENT SCIENCES

Vol. 11, No. 3, 2021, E-ISSN: 2225-8329 @ 2021 HRMARS

(Alsharif et al., 2020a; Alsharif et al., 2021d). Moreover, this paper has been structured based on the Preferred Reporting Items for Systematic Reviews and Meta-Analyses (PRISMA) framework of Moher et al. (2015) to extract the relevant document in neuromarketing and consumer neuroscience for this study to fill the gap in the literature. The current study is designed to extract documents from the Scopus database to answer the research questions. Additionally, instructions of Block \& Fisch (2020) has been followed to present an impactful bibliometric analysis and assessing the structure of a specific area by identifying the most productive countries, academic institutions, journals, and authors with a brief description of each section. VOSviewer software has been used to map the literature of this study as it is a powerful/impactful tool to create a visualisation view/map according to the area of interest. This VOSviewer has been widely used in bibliometric research in various domains, for example, in neuromarketing (Alsharif et al., 2021a; Alsharif et al., 2020a; Alsharif et al., 2021d), service quality in healthcare (Ali et al., 2021a), Services and Service Quality (Ali et al., 2021b), mobile healthcare (Ali et al., 2021c), electronic word of mouth (Ewom) (Abbas et al., 2020). Figure 1 shows the structure, indicators, and tools that have been used in this study. These processes will give us a deep insight into developing in the neuromarketing field. Additionally, it would provide us with a comprehensive understanding of the most productive (e.g., academics institutions, authors) to be considered for further neuromarketing research. Therefore, the findings provide a guide for scholars who are interested in neuromarketing and consumer neuroscience field.

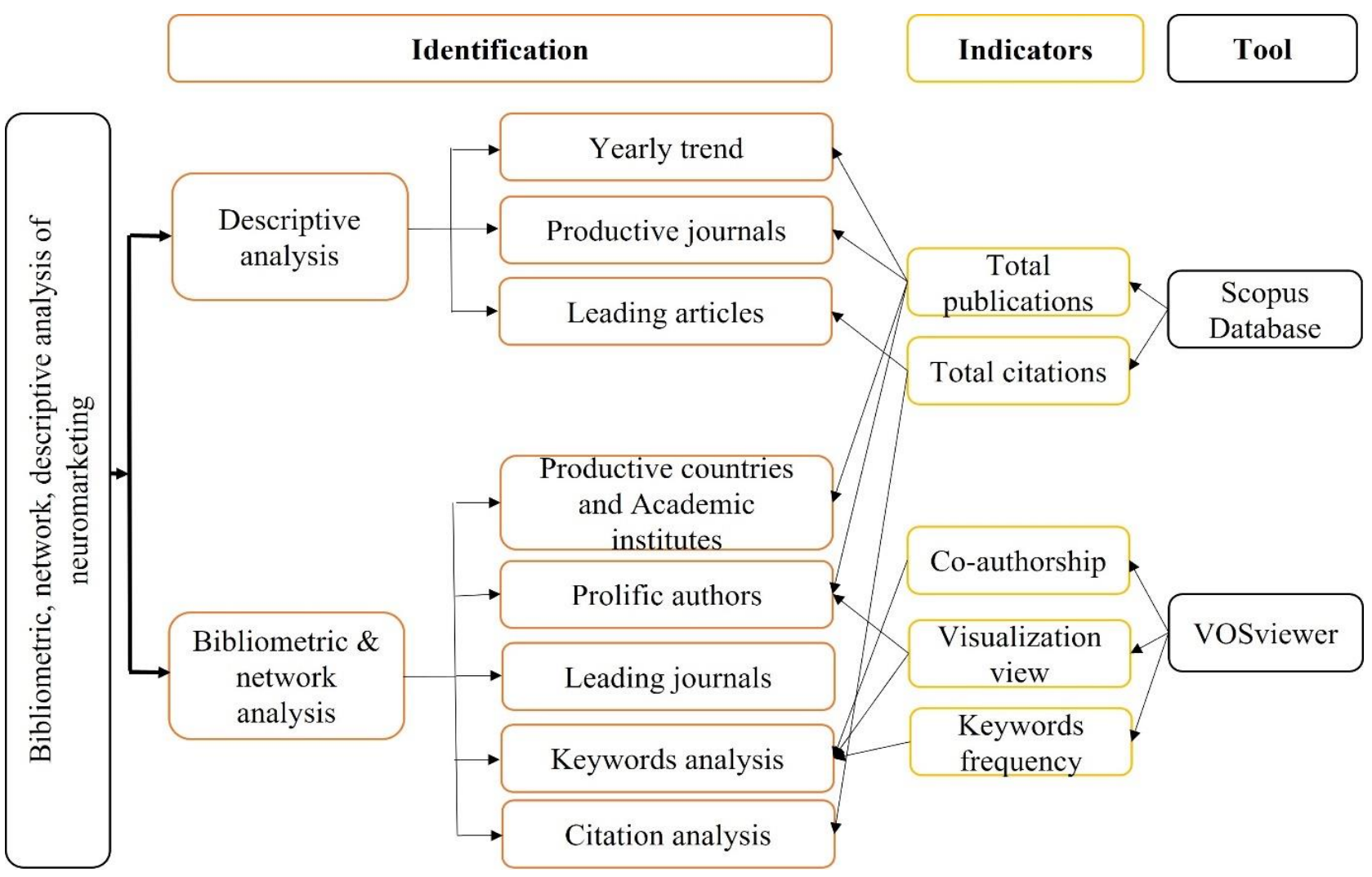

Fig. 1. Analytical structure of the current paper.

\section{Search Criteria}

Data collection was carried out in August 2021 from the Scopus database. Many various studies have been conducted by using the Scopus database. Researchers and institutions 
MANAGEMENT SCIENCES

Vol. 11, No. 3, 2021, E-ISSN: 2225-8329 @ 2021 HRMARS

widely use the Scopus database to know the current status of a specific field. It provides researchers with the chance to import a bibliography database such as affiliations, references, publishers, citations, and so forth. This search has been limited by using the following query applied to the title, abstract, and keywords: ("neuromarketing" OR "consumer neuroscience"). The total number of publications was 635 documents from 2008-2021. It has extracted 143 papers (126 articles, 17 review articles) from the Scopus database. As shown in Figure 2, we followed PRISMA framework, which includes four stages: (i) identification as recording identified through database searching, (ii) screening the record publications, (iii) eligibility means assessment of the eligible publications for this review, and (iv) selecting and including studies, as follow:

- Documents (i.e., articles and reviews) published in neuromarketing or consumer neuroscience from 2008-2021 were included.

- Documents that used neuromarketing tools were included.

- Documents published in the non-English language were excluded.

- Documents (e.g., book chapter, conference, etc.) were excluded.

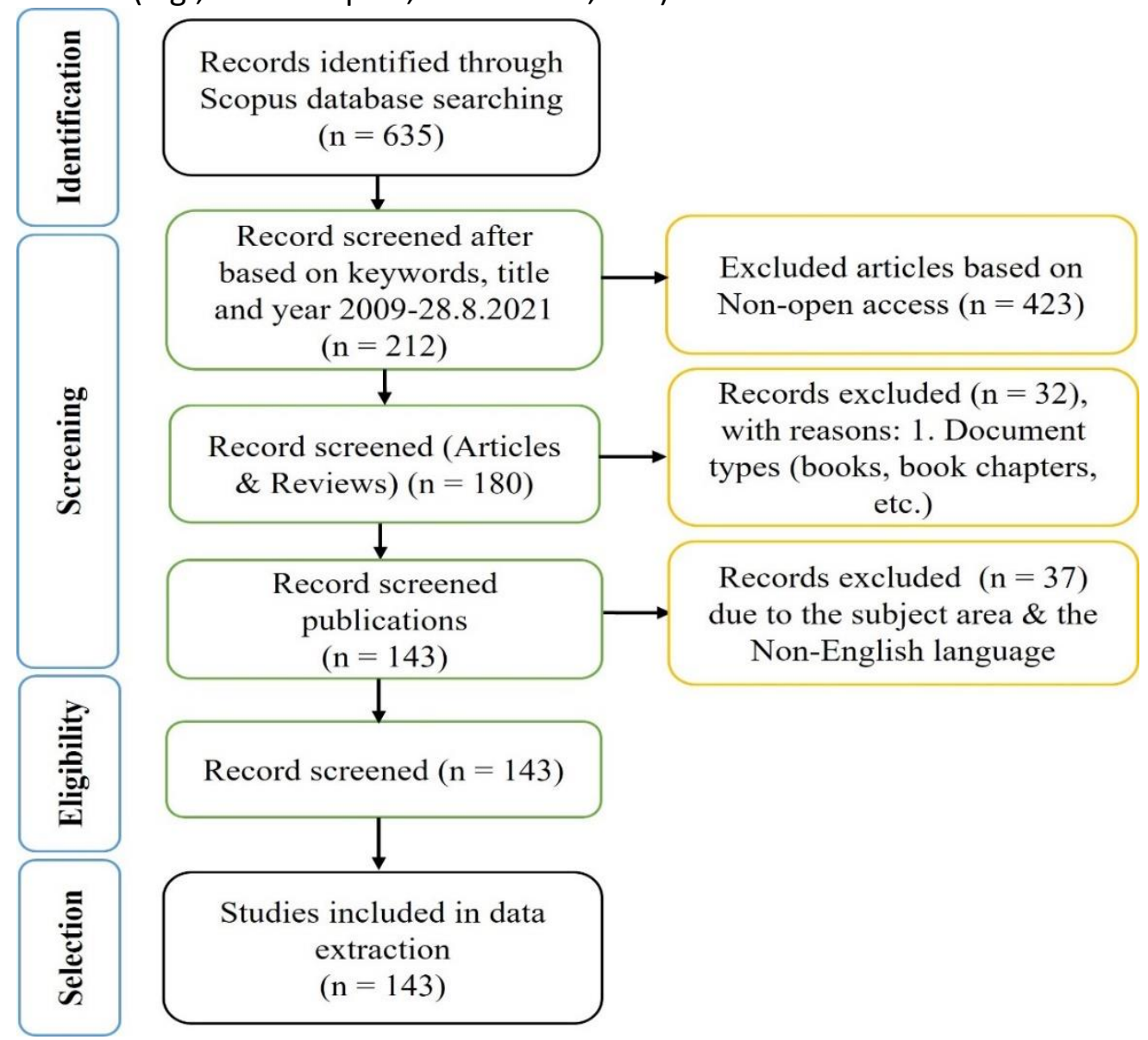

Fig. 2. PRISMA flow chart for selecting documents for this study.

\section{Results}

\section{Descriptive Analysis}

A descriptive analysis of hundred-forty-three documents has been followed. These papers were used neuromarketing tools to know the global trend in the advertising domain in terms of annual and cumulative publications, countries/academic institutions, and journals. 


\section{Growth of the Publication}

Hundred-forty-three documents have been published in an academic journal that belongs to the Scopus database related to neuromarketing/consumer neuroscience, which has been used the neuroscience tools. The first article in neuromarketing/consumer neuroscience was published in 2008, investigating branding and memory-based brand choice (Walvis, 2008). In addition, the first academic publication in advertising within the neuromarketing domain was published in 2009, which was investigated the neural responses of emotion (e.g., pleasure, arousal) toward TV advertising by using functional magnetic resonance imaging (fMRI) Morris et al. (2009). It has seen an increase in publications number from 2008-2021, but the most remarkable growth was noticed in the last five years; it has published more than 100 documents between 2017 and August 2021, as depicted in Figure 3. In addition, it is expected that the number of publications will be increased at the end of 2021 to exceed 40 articles.

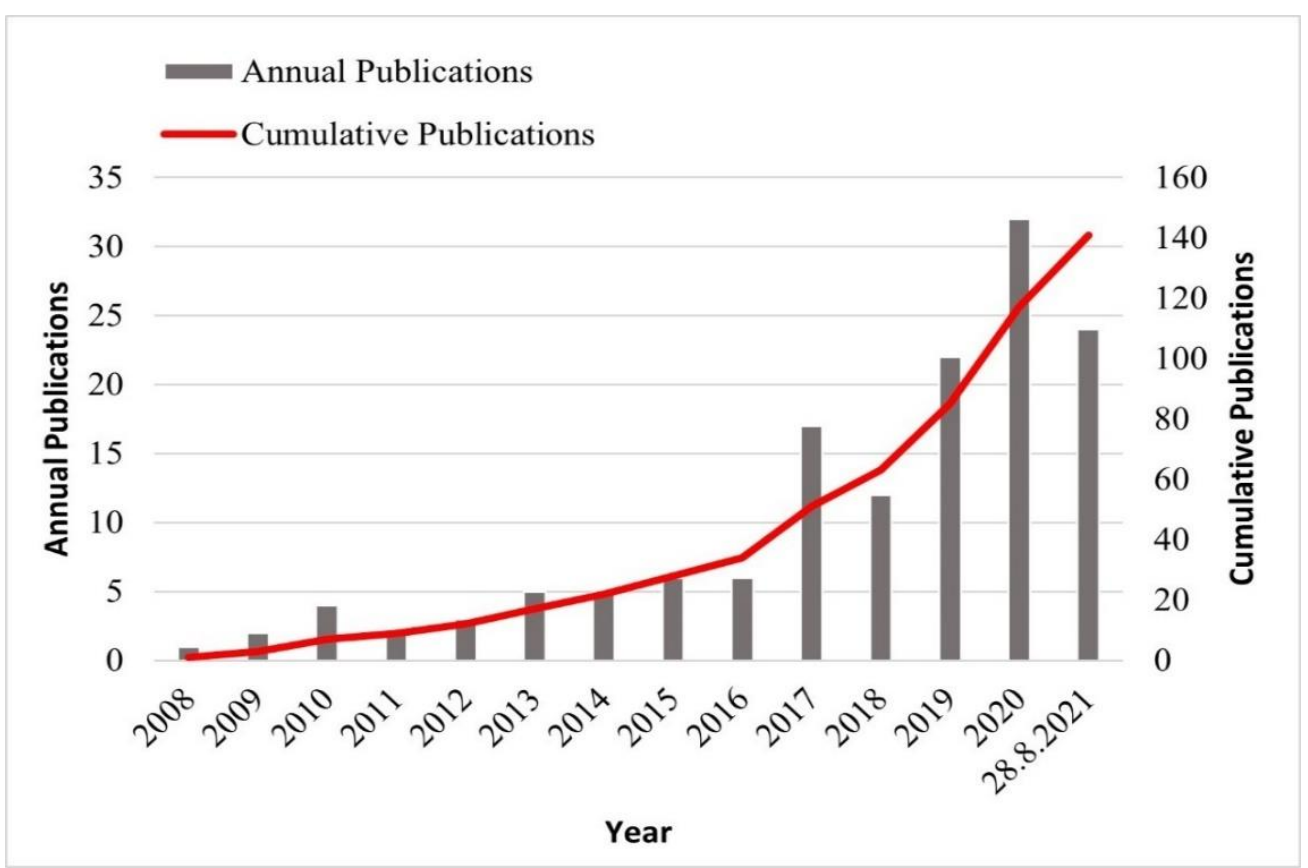

Fig. 3. The annual and cumulative publications in advertising and neuromarketing.

\section{Journal Outlets}

The findings revealed that ten most journals belong to seven publishers and six countries, as tabulated in Table 1. For example, Frontiers Media Sa and MDPI publishers are the leading players in the neuromarketing/consumer neuroscience domain, with forty-four publications representing almost $31 \%$ of total articles. The most three productive journals belong to Frontiers Media Sa. The rest of the articles (99 articles) were published by Taylor \& Francis AS, Grupo Communicar, Edizioni Univ. Lettere Economic Diritto-Led, Elsevier, and Public Library Science. Furthermore, the most productive journal was the Frontiers in Psychology, with 17 articles that represent almost $12 \%$ of total articles. Followed by Frontiers in Neuroscience (almost $8 \%$ ), which published the most second cited article with 65 citations by Lin et al. (2014). Journal of Economic Psychology published the most cited article with 67 citations by Solnais et al. (2013). According to Cite Score in 2020, four journals have a Citescore higher than 5. Interestingly, Comunicar has the highest Cite Score (7.3) despite 
MANAGEMENT SCIENCES

Vol. 11, No. 3, 2021, E-ISSN: 2225-8329 @ 2021 HRMARS

being the fourth position in the list. The second highest Cite Score belongs to Frontiers in

Neuroscience (5.4).

Table 1. The most Productive journal in neuromarketing and advertising (with min. 2 documents).

\begin{tabular}{|c|c|c|c|c|c|c|c|}
\hline $\begin{array}{l}\text { Source/ } \\
\text { Journal }\end{array}$ & TP & $\begin{array}{l}\mathrm{TC} \\
28.8 . \\
2021 \\
\end{array}$ & $\begin{array}{l}\text { Cite } \\
\text { Score } \\
2020 \\
\end{array}$ & $\begin{array}{l}\text { Reference of } \\
\text { the most cited } \\
\text { document }\end{array}$ & $\begin{array}{l}\text { Time } \\
\text { cited }\end{array}$ & Publisher & Country \\
\hline $\begin{array}{l}\text { Frontiers in } \\
\text { Psychology }\end{array}$ & 17 & 52 & 3.5 & $\begin{array}{l}\text { Guixeres et al. } \\
(2017)\end{array}$ & 36 & $\begin{array}{l}\text { Frontiers } \\
\text { Media Sa }\end{array}$ & Switzerland \\
\hline $\begin{array}{l}\text { Frontiers in } \\
\text { Neuroscience }\end{array}$ & 11 & 169 & 5.4 & Lin et al. (2014) & 65 & $\begin{array}{l}\text { Frontiers } \\
\text { Media Sa }\end{array}$ & Switzerland \\
\hline $\begin{array}{l}\text { Frontiers in } \\
\text { Human } \\
\text { Neuroscience }\end{array}$ & 7 & 40 & 5.1 & $\begin{array}{l}\text { Breiter et al. } \\
(2015)\end{array}$ & 22 & $\begin{array}{l}\text { Frontiers } \\
\text { Media Sa }\end{array}$ & Switzerland \\
\hline $\begin{array}{l}\text { Cogent } \\
\text { Psychology }\end{array}$ & 5 & 55 & 1.4 & $\begin{array}{l}\text { Bosshard et al. } \\
\text { (2016) }\end{array}$ & 26 & $\begin{array}{l}\text { Taylor \& } \\
\text { Francis AS }\end{array}$ & England \\
\hline Comunicar & 5 & 79 & 7.3 & $\begin{array}{l}\text { Cuesta-Cambra } \\
\text { et al. (2017) }\end{array}$ & 22 & $\begin{array}{l}\text { Grupo } \\
\text { Comunicar }\end{array}$ & Spain \\
\hline Sustainability & 5 & 9 & 3.9 & $\begin{array}{l}\text { Constantinescu } \\
\text { et al. (2019) }\end{array}$ & 6 & MDPI & Switzerland \\
\hline $\begin{array}{l}\text { Behavioral } \\
\text { Science }\end{array}$ & 4 & 10 & 3.4 & $\begin{array}{l}\text { Harris et al. } \\
(2019)\end{array}$ & 8 & MDPI & Switzerland \\
\hline $\begin{array}{l}\text { Neuropsycholo } \\
\text { gical Trends }\end{array}$ & 4 & 22 & 1.4 & $\begin{array}{l}\text { Balconi et al. } \\
(2014)\end{array}$ & 14 & $\begin{array}{l}\text { Edizioni } \\
\text { Univ Lettere } \\
\text { Economic } \\
\text { Diritto-Led }\end{array}$ & Italy \\
\hline $\begin{array}{l}\text { Journal of } \\
\text { Economic } \\
\text { Psychology }\end{array}$ & 3 & 144 & 3.4 & $\begin{array}{l}\text { Solnais et al. } \\
\text { (2013) }\end{array}$ & 67 & Elsevier & Netherlands \\
\hline PloS ONE & 3 & 19 & 5.3 & $\begin{array}{l}\text { Minguillon et } \\
\text { al. (2017) }\end{array}$ & 14 & $\begin{array}{l}\text { Public } \\
\text { Library } \\
\text { Science }\end{array}$ & USA \\
\hline
\end{tabular}

TP; total publication, TC; total citations

\section{Bibliometric Analysis}

Productive Countries and Institutions

A total of hundred-forty-three documents have been extracted from the Scopus database have been analysed. Table 2 shows that four countries (i.e., Spain, UK, USA, and Italy) are the key players in the neuromarketing domain, which have published more than $50 \%$ of the total documents. That led to infer that these countries play a vital role in the blossoming of studies in neuromarketing. Additionally, Spain is the most productive country with 27 documents (approximately $19 \%$ of total documents), followed by the UK as the second-productive country with 19 documents (13\%). Although the USA ranked third in the list with 17 publications (12\%), its institute (Emory University) has published the most cited articles with 566 citations. The rest countries were contributed with less than $10 \%$ of the total publications each. Moreover, according to the most prolific academic institutions, Universidad 
MANAGEMENT SCIENCES

Vol. 11, No. 3, 2021, E-ISSN: 2225-8329 @ 2021 HRMARS

Complutense de Madrid has published nine documents with 35 citations, followed by Sapienza Università di Roma with six publications and the second-highest citations (164 citations). The University of Oxford with five publications and 78 citations. However, Emory University has published two documents with the highest citations (566 citations). The remained academic institutions published less than four documents each.

Table 2. The most productive authors in the neuromarketing domain (minimum contributions three documents).

\begin{tabular}{lllllll}
\hline Country & TP & TC & $\begin{array}{l}\text { H- } \\
\text { index }\end{array}$ & The most prolific academic institutions & TPi & TCi \\
\hline Spain & 27 & 221 & 7 & Universidad Complutense de Madrid & 9 & 35 \\
UK & 19 & 294 & 8 & University of Oxford & 5 & 78 \\
USA & 17 & 1103 & 10 & Emory University & 2 & 566 \\
Italy & 13 & 187 & 6 & Sapienza Università di Roma & 6 & 164 \\
China & 12 & 164 & 6 & Hangzhou Dianzi University & 4 & 124 \\
Malaysia & 11 & 87 & 4 & Universiti Teknologi Malaysia & 3 & 4 \\
Germany & 10 & 173 & 5 & Universität zu Lübeck & 2 & 15 \\
Netherlands & 10 & 103 & 5 & Erasmus Universiteit Rotterdam & 3 & 49 \\
Australia & 5 & 80 & 4 & Swinburne University of Technology & 2 & 36 \\
Lithuania & 5 & 15 & 2 & Vytautas Magnus university & 3 & 11 \\
\hline
\end{tabular}

TP; total publication, TC; total citations, TPi; total publications by institution, $\mathrm{TCi}$; total citation for the institution

\section{Leading Authors}

The fifteen top prolific authors who have published at least three documents in neuromarketing are affiliated to ten countries, as tabulated in Table 3. These authors have published a total of 52 documents, which indicates a high collaboration among them. Seven of them have published four documents each, and the remaining authors have published three documents each. For example, Babiloni, F. from Italy; Kong, W. from China; Schneider, T. from Switzerland; Woolgar, S. from Sweden; Ma, Q. from China; Tur-Viñes, V. from Spain; and Mañas-Viniegra, L. from Spain are the most productive authors with the same number of publication each (four documents) and $143 ; 124 ; 51 ; 51 ; 18 ; 15$; and 11 citations, respectively. The remained authors published the same number of documents each (three documents). Although Vecchiato, G. in 8th position in the list, he published the most third-cited article with 118 citations. 
MANAGEMENT SCIENCES

Vol. 11, No. 3, 2021, E-ISSN: 2225-8329 @ 2021 HRMARS

Table 3. The most ten productive countries and academic institutions.

\begin{tabular}{|c|c|c|c|c|}
\hline Author's name & TP & $\begin{array}{l}\text { TC } 28.8 . \\
2021\end{array}$ & Affiliation & Country \\
\hline Babiloni, F. & 4 & 143 & $\begin{array}{l}\text { Sapienza University Rome; Brainsigns } \\
\text { SRL }\end{array}$ & Italy \\
\hline Kong, W. & 4 & 124 & Hangzhou Dianzi University & China \\
\hline Schneider, T. & 4 & 51 & University of St. Gallen & Switzerland \\
\hline Woolgar, S. & 4 & 51 & Linköpings Universitet & Sweden \\
\hline $\mathrm{Ma}, \mathrm{Q}$ & 4 & 18 & Zhejiang University of Technology & China \\
\hline Tur-Viñes, V. & 4 & 15 & Universitat d'Alacant & Spain \\
\hline Mañas-Viniegra, L. & 4 & 11 & Universidad Complutense de Madrid & Spain \\
\hline Vecchiato, G. & 3 & 118 & Consiglio Nazionale delle Ricerche & Italy \\
\hline Lee, $\mathrm{N}$. & 3 & 59 & Warwick Business School, & UK \\
\hline Smidts, A. & 3 & 49 & Erasmus University & Netherlands \\
\hline Cherubino, $\mathrm{P}$. & 3 & 47 & $\begin{array}{l}\text { Sapienza University Rome; Brainsigns } \\
\text { SRL }\end{array}$ & Italy \\
\hline Ramsøy, T.Z. & 3 & 45 & Neurons Inc & Denmark \\
\hline $\begin{array}{l}\text { Grigaliunaite, } \\
\text { Viktorija }\end{array}$ & 3 & 11 & Vytautas Magnus University & Lithuania \\
\hline Pileliene, Lina & 3 & 11 & Vytautas Magnus University & Lithuania \\
\hline Alsharif, Ahmed H. & 3 & 4 & Universiti Teknologi Malaysia & Malaysia \\
\hline
\end{tabular}

\section{Leading Journals}

The most ten productive journals in neuromarketing have been identified, which have published at least three documents (Table 4). Frontiers in Psychology has been ranked as the most prolific journal, with 17 documents (approximately $12 \%$ of total documents), while the rest of the journals have published documents less than $10 \%$ each. To identify the productivity and impact of journals in neuromarketing, we have followed the number of publications for each author as an indicator of productivity and the average citation per item (Cuesta-Cambra et al.) as an indicator of journal impact. ACi has been calculated based on the number of citations and publications from the Scopus database, as tabulated in Table 4. Although the Journal of Economic Psychology has only three publications in neuromarketing, it has the highest $\mathrm{ACi}$ in the list with 48 citations. Followed by the Comunicar with 15.8 citations. These findings illustrate that a large number of publications does not necessarily reflect a large number of citations. 
MANAGEMENT SCIENCES

Vol. 11, No. 3, 2021, E-ISSN: 2225-8329 @ 2021 HRMARS

Table 4. The most Productive journal in neuromarketing and advertising (with min. 3 documents).

\begin{tabular}{llll}
\hline Source/Journal & TP & TC & ACi \\
& & $\mathbf{2 8 . 8 . 2 0 2 1}$ & \\
\hline Frontiers in Psychology & 17 & 52 & 3.1 \\
Frontiers in Neuroscience & 11 & 169 & 15.4 \\
Frontiers in Human Neuroscience & 7 & 40 & 5.7 \\
Cogent Psychology & 5 & 55 & 11 \\
Comunicar & 5 & 79 & 15.8 \\
Sustainability & 5 & 9 & 1.8 \\
Behavioral Science & 4 & 10 & 2.5 \\
Neuropsychological Trends & 4 & 22 & 5.5 \\
Journal of Economic Psychology & 3 & 144 & 48 \\
PloS ONE & 3 & 19 & 6.3 \\
\hline
\end{tabular}

$\mathrm{ACi}$; average citation per item

\section{Keywords Analysis}

The keywords occurrences are expressed in a numerical method in bibliometric analysis (Wang \& Chai, 2018) to investigate keywords, which provide a coherent interpretation of the articles' content (Alsharif et al., 2021c; Comerio \& Strozzi, 2019). Meanwhile, the correlation between a couple of keywords is also expressed in a numerical value, which refers to link strength between these two keywords; a higher numerical value means a stronger link (Ravikumar et al., 2015). The link strength between two keywords represents the number of appearances of both keywords in the same article. The total number of links indicates the aggregate number of appearances together in the same document. In VOSviewer, we set five as the minimum occurrences of author keywords, which means keywords will appear on the bibliometric map at least five times between these two keywords that occur together in the same document. In this study, author keywords co-occurrence analysis has been carried out, which involved 21 keywords from 143 articles in 76 journals with minimum number five of keyword occurrences.

Co-occurrence keywords analysis is essential to provide general ideas/claims about the articles' content (Comerio \& Strozzi, 2019). Additionally, it is an effective technique to address the research directions and evaluate the hot themes in a specific topic (e.g., neuromarketing) by exploring the recent academic documents in neuromarketing trends (Alsharif et al., 2021d). As we can see from the map of the keywords co-occurrences (Figure 5), neuromarketing focused on consumer behaviour such as emotion (18 occurrences, 37 TLS), decision-making (11 occurrences, 26 TLS), attention (8 occurrences, 27 TLS); marketing stimuli such as advertising ( 6 occurrences, 21 total link strength (TLS)), brands (5 occurrences, 11 TLS); and tools such as EEG (20 occurrences, 44 TLS), ET (16 occurrences, 24 TLS), fMRI (8 occurrences, 20 TLS), ERP (5 occurrences, 21 TLS), GSR (5 occurrences, 15 TLS). For example, emotion (18 occurrences, 37 TLS) means emotion occurrence 18 times, and the TLS for this aggregate appearance is 37 links with neuromarketing theme. Finally, we can notice that neuromarketing uses neuroscience tools such as EEG to study the consumers' behaviour (e.g., emotion) toward marketing stimuli (e.g., advertising). 


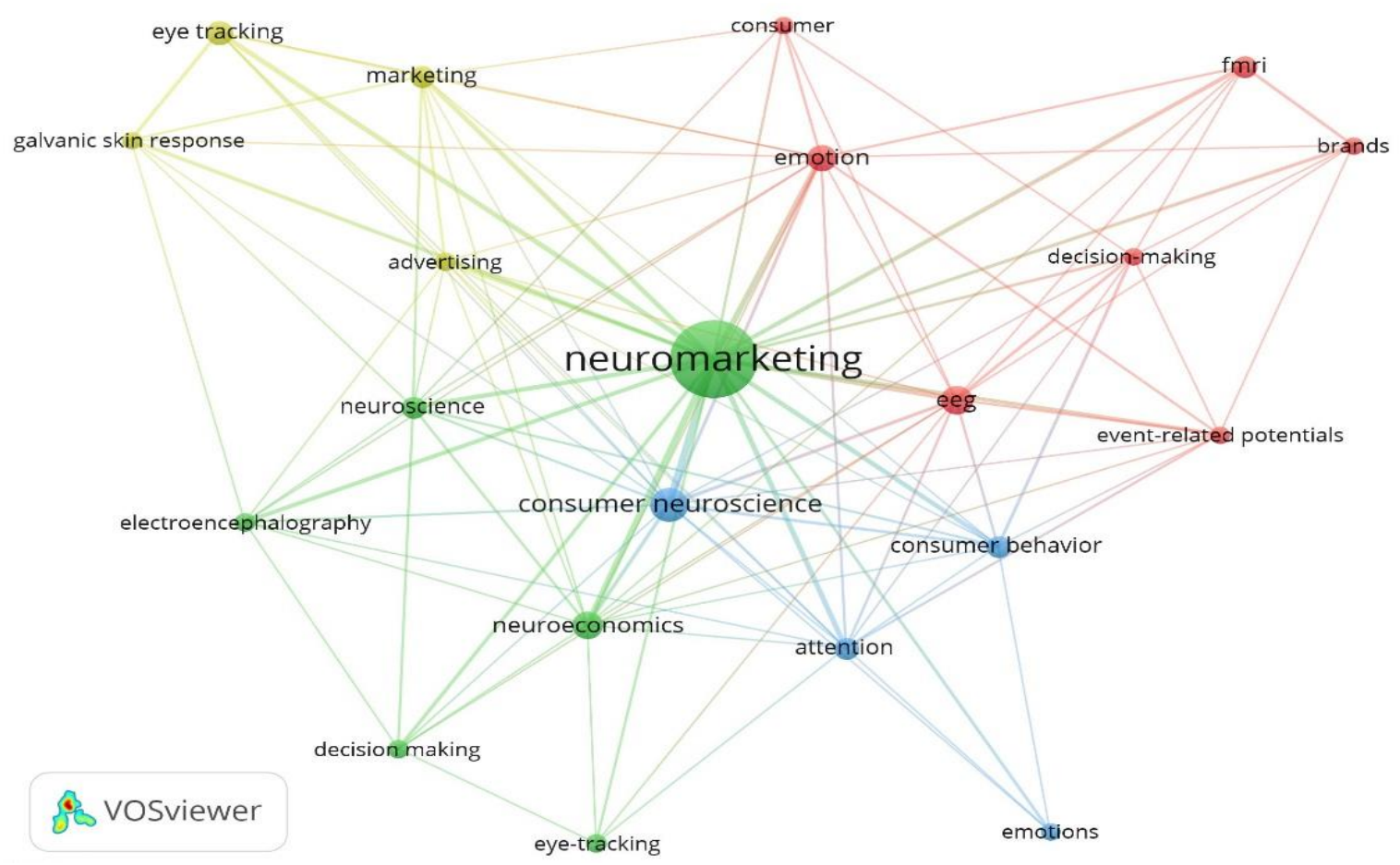

Fig. 4. All keywords co-occurrence (with min. 5 occurrence).

Additionally, we were expected that there is a strong correlation between neuromarketing with neuroimaging tools (e.g., EEG, ERP, GSR, ET, and fMRI), the brain processes (e.g., attention, emotion), and marketing stimuli (e.g., advertising, brands). Furthermore, it has been noticed that "EEG" is highly connected with neuromarketing. Table 7 summarises the most frequent keywords with minimum of 5 occurrences, wherein the highest keyword occurrence is neuromarketing.

Table 5. Top keywords by the minimum 5 occurrences.

\begin{tabular}{lll}
\hline Keyword & Occurrences/Frequency & Total Link Strength \\
\hline Neuromarketing & 100 & 185 \\
Consumer neuroscience & 19 & 57 \\
EEG & 20 & 44 \\
Neuroeconomics & 13 & 39 \\
Emotion & 18 & 37 \\
ET & 16 & 24 \\
Decision making & 11 & 26 \\
Attention & 8 & 27 \\
neuroscience & 8 & 27 \\
Marketing & 8 & 26 \\
Consumer behaviour & 8 & 25 \\
fMRI & 8 & 20 \\
Advertising & 6 & 21 \\
ERP & 5 & 21 \\
GSR & 5 & 15 \\
Brands & 5 & 11 \\
Consumer & 5 & 8 \\
\hline
\end{tabular}




\section{Citation Analysis}

We have used citations analysis as an indicator of articles impact in neuromarketing. Citation analysis is important to identify the most impactful articles in a particular subject by determining the number of citations to these documents from others (Kumar et al., 2019). We have reviewed and analysed the citations of 143 articles (126 articles and 17 review articles). Table 6 shows the most-cited articles in the neuromarketing domain with more than 40 citations. We found that four articles with more than 100 citations. For example, the mostcited article is "Neuromarketing: The hope and hype of neuroimaging in business" with 426 citations, which has been written by Ariely \& Berns (2010), published in Nature Reviews Neuroscience. Article title " From neural responses to population behaviour: Neural focus group predicts population-level media effects" is the second-highest citations article (167 citations) at the end of August 2021, which was written by Falk et al. (2012), published in Psychological Science. The third most-cited article in the list is "A neural predictor of cultural popularity", with 140 citations, which was published by Berns \& Moore (2012) in the Journal of Consumer Psychology. Communications of the Association for Information Systems published an article title "On the foundations of neurois: Reflections on the gmunden retreat 2009" with 108 citations (Riedl et al., 2010). Finally, the rest of the articles with less than 100 citations. 
Table 6. The top articles on Scopus database by citation score with minimum 40 citations.

\begin{tabular}{|c|c|c|c|c|}
\hline Document Title & Authors/Year & Journal & Type & $\begin{array}{l}\text { TC } \\
28.8 . \\
2021\end{array}$ \\
\hline $\begin{array}{l}\text { Neuromarketing: The hope and hype } \\
\text { of neuroimaging in business }\end{array}$ & $\begin{array}{l}\text { Ariely \& Berns } \\
\text { (2010) }\end{array}$ & $\begin{array}{l}\text { Nature Reviews } \\
\text { Neuroscience }\end{array}$ & Review & 426 \\
\hline $\begin{array}{l}\text { From neural responses to population } \\
\text { behavior: Neural focus group predicts } \\
\text { population-level media effects }\end{array}$ & $\begin{array}{l}\text { Falk et al. } \\
(2012)\end{array}$ & $\begin{array}{l}\text { Psychological } \\
\text { Science }\end{array}$ & Article & 167 \\
\hline $\begin{array}{l}\text { A neural predictor of cultural } \\
\text { popularity }\end{array}$ & $\begin{array}{lr}\text { Berns } \quad \& \\
\text { Moore (2012) }\end{array}$ & $\begin{array}{l}\text { Journal } \\
\text { Consumer } \\
\text { Psychology }\end{array}$ & Article & 140 \\
\hline $\begin{array}{l}\text { On the foundations of Neurols: } \\
\text { Reflections on the Gmunden retreat } \\
2009\end{array}$ & $\begin{array}{l}\text { Riedl et al. } \\
(2010)\end{array}$ & $\begin{array}{l}\text { Communications } \\
\text { of the } \\
\text { Association for } \\
\text { Information } \\
\text { Systems }\end{array}$ & Article & 108 \\
\hline $\begin{array}{l}\text { On the Use of EEG or MEG brain } \\
\text { imaging tools in neuromarketing } \\
\text { research }\end{array}$ & $\begin{array}{l}\text { Vecchiato et } \\
\text { al. (2011) }\end{array}$ & $\begin{array}{l}\text { Computational } \\
\text { Intelligence and } \\
\text { Neuroscience }\end{array}$ & Review & 83 \\
\hline $\begin{array}{l}\text { The contribution of neuroscience to } \\
\text { consumer research: A conceptual } \\
\text { framework and empirical review }\end{array}$ & $\begin{array}{l}\text { Solnais et al. } \\
(2013)\end{array}$ & $\begin{array}{l}\text { Journal of } \\
\text { Economic } \\
\text { Psychology }\end{array}$ & Review & 67 \\
\hline $\begin{array}{l}\text { Fusion of electroencephalographic } \\
\text { dynamics and musical contents for } \\
\text { estimating emotional responses in } \\
\text { music listening }\end{array}$ & $\begin{array}{l}\text { Lin et al. } \\
(2014)\end{array}$ & $\begin{array}{l}\text { Frontiers in } \\
\text { Neuroscience }\end{array}$ & Article & 65 \\
\hline $\begin{array}{l}\text { Branding and a child's brain: An fMRI } \\
\text { study of neural responses to logos }\end{array}$ & $\begin{array}{l}\text { Bruce et al. } \\
(2014)\end{array}$ & $\begin{array}{l}\text { Social Cognitive } \\
\text { and Affective } \\
\text { Neuroscience }\end{array}$ & Article & 51 \\
\hline $\begin{array}{l}\text { Celebrities and shoes on the female } \\
\text { brain: The neural correlates of } \\
\text { product evaluation in the context of } \\
\text { fame }\end{array}$ & $\begin{array}{l}\text { Stallen et al. } \\
(2010)\end{array}$ & $\begin{array}{l}\text { Journal of } \\
\text { Economic } \\
\text { Psychology }\end{array}$ & Article & 49 \\
\hline $\begin{array}{l}\text { Affective characterisation of movie } \\
\text { scenes based on content analysis and } \\
\text { physiological changes }\end{array}$ & $\begin{array}{l}\text { Soleymani et } \\
\text { al. (2009) }\end{array}$ & $\begin{array}{l}\text { International } \\
\text { Journal of } \\
\text { Semantic } \\
\text { Computing }\end{array}$ & Article & 44 \\
\hline
\end{tabular}

\section{Co-citation Analysis}

Co-citation also helps to identify the structure of the literature on a specific topic (Block \& Fisch, 2020). In addition, it helps researchers to determine the content and topic domain by evaluating the most-cited reference together. It is an indicator of the appearance of two authors names in one document. We have used the VOSviewer software to measure the correlation between a couple of authors by using the link strength between them; wherein the total number refers to the link strength between these both authors (Van Eck \& Waltman, 2013). Table 9 shows the number of link strengths between a couple of authors, wherein a 
MANAGEMENT SCIENCES

Vol. 11, No. 3, 2021, E-ISSN: 2225-8329 @ 2021 HRMARS

higher number means a higher correlation between both authors. We found that 21 pairs of articles co-cited with each other at least two times. We also found that the number of link strengths between Ariely \& Berns (2010) and Berns \& Moore (2012) is 13 links, as the strongest co-citation correlation between a couple of authors. The link strength between Solnais et al. (2013) and Vecchiato et al. (2011) was the second-strongest co-citation between a couple of authors with ten links. Followed by Riedl et al. (2010) and Solnais et al. (2013) with seven links. These findings confirm our discussion in the body of literature in neuromarketing, wherein neuromarketing focuses on the consumer's behaviours toward marketing stimuli.

Table 7. The top document pairs with more than two link strengths.

\begin{tabular}{|c|c|c|c|}
\hline Document title & Author 1 & Author 2 & $\begin{array}{l}\text { Link } \\
\text { Strength } \\
\text { between } \\
\text { Authors 1, } \\
2\end{array}$ \\
\hline $\begin{array}{l}\text { Neuromarketing: The hope and hype of } \\
\text { neuroimaging in business }\end{array}$ & $\begin{array}{l}\text { Ariely } \\
\text { Berns } \\
(2010)\end{array}$ & $\begin{array}{l}\text { Berns } \\
\text { Moore } \\
(2012)\end{array}$ & 13 \\
\hline $\begin{array}{l}\text { The contribution of neuroscience to consumer } \\
\text { research: A conceptual framework and } \\
\text { empirical review }\end{array}$ & $\begin{array}{l}\text { Solnais et al. } \\
(2013)\end{array}$ & $\begin{array}{l}\text { Vecchiato et } \\
\text { al. (2011) }\end{array}$ & 10 \\
\hline $\begin{array}{l}\text { On the foundations of NeurolS: reflections on } \\
\text { the Gmunden Retreat } 2009\end{array}$ & $\begin{array}{l}\text { Riedl et al. } \\
(2010)\end{array}$ & $\begin{array}{l}\text { Solnais et al. } \\
\text { (2013) }\end{array}$ & 7 \\
\hline A neural predictor of cultural popularity & $\begin{array}{l}\text { Berns \& } \\
\text { Moore } \\
(2012)\end{array}$ & $\begin{array}{l}\text { Solnais et al. } \\
\text { (2013) }\end{array}$ & 6 \\
\hline $\begin{array}{l}\text { Branding and a child's brain: An fMRI study of } \\
\text { neural responses to logos }\end{array}$ & $\begin{array}{l}\text { Bruce et al. } \\
\text { (2014) }\end{array}$ & $\begin{array}{l}\text { Solnais et al. } \\
\text { (2013) }\end{array}$ & 4 \\
\hline $\begin{array}{l}\text { From Neural Responses to Population } \\
\text { Behavior: Neural Focus Group Predicts } \\
\text { Population-Level Media Effects }\end{array}$ & $\begin{array}{l}\text { Falk et al. } \\
(2012)\end{array}$ & $\begin{array}{l}\text { Solnais et al. } \\
(2013)\end{array}$ & 2 \\
\hline $\begin{array}{l}\text { Fusion of electroencephalographic dynamics } \\
\text { and musical contents for estimating } \\
\text { emotional responses in music listening }\end{array}$ & $\begin{array}{l}\text { Lin et al. } \\
(2014)\end{array}$ & $\begin{array}{l}\text { Vecchiato et } \\
\text { al. (2011) }\end{array}$ & 2 \\
\hline
\end{tabular}

\section{Co-citation Network}

VOSviewer software has been used for the analysis of the co-citation network. It has identified three clusters: thereby, studying, exploring, and understanding the structure and nature of neuromarketing. We found more than 40 times; co-citation occurred in 10 documents. We followed the instructions recommended by Baker et al. (2020) to visualise the co-citation network map of the top ten articles by using VOSviewer software. The findings revealed that three clusters with high correlations between them (Figure 6). The green cluster is the highest cluster that was dominated by Ariely \& Berns (2010), with 615 total citations. Red is the second-highest cluster, which is leading by Falk et al. (2012). The red cluster has 476 citations, while the blue cluster has 109 citations leading by Lin et al. (2014). Although these clusters/groups address various aspects of neuromarketing, they are highly interconnected and complementary. 


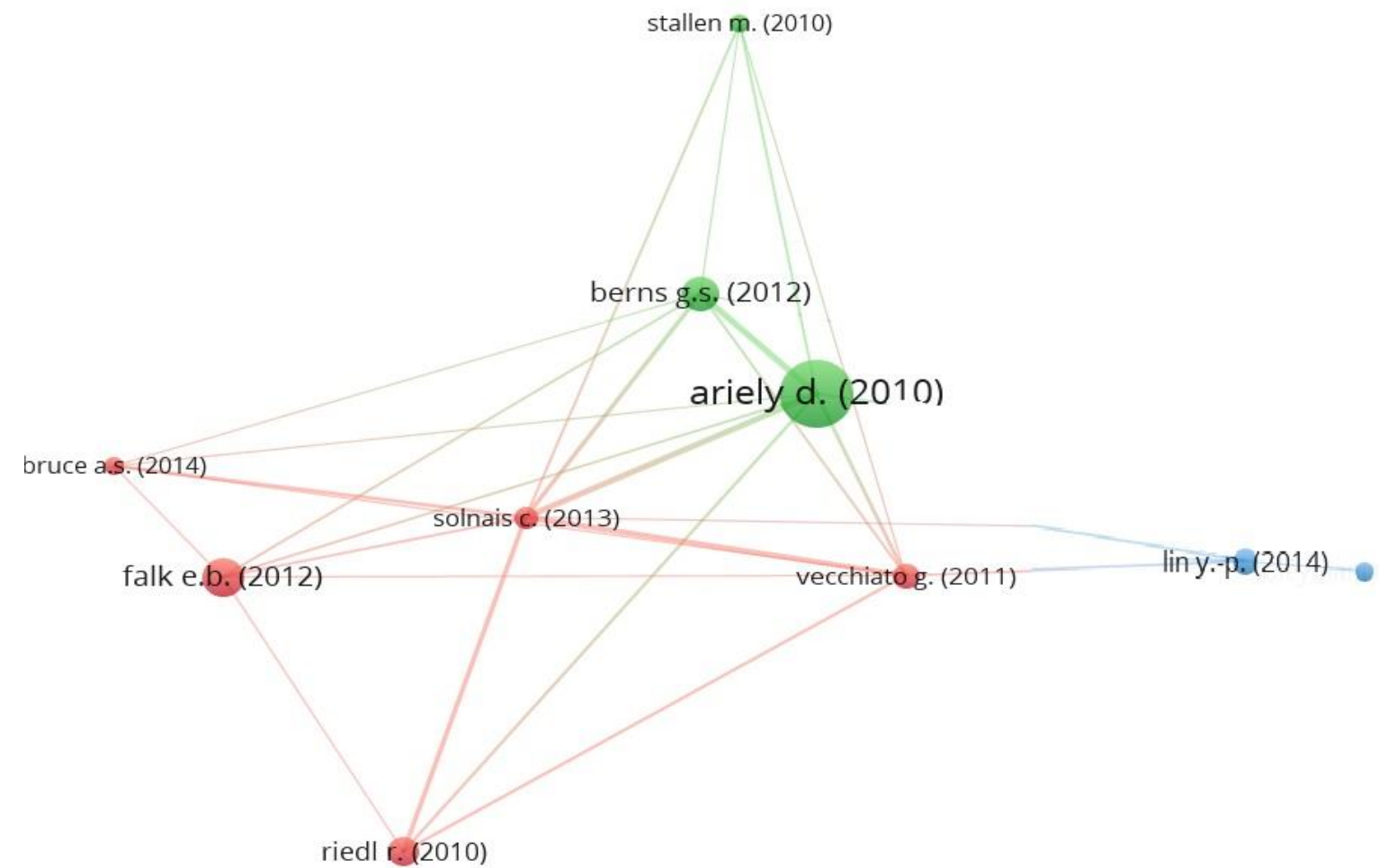

Fig. 5. Map of 10 documents with minimum of 40 citations.

\section{Discussion}

In the last decade, most studies concentrated on studying consumer behaviour toward marketing stimuli such as but not limited to advertising. Neuromarketing is used neuroscientific tools such as $\mathrm{fMRI}$ to record, study, analysis the unconscious reactions of consumers toward marketing stimuli. We followed the PRISMA framework to extract the relevant documents, which related to neuromarketing or consumer neuroscience. Additionally, we used bibliometric analysis to know the global trends in the neuromarketing field, such as the most productive journal, countries, academic institutions, authors, and the number of documents and citations. The finding revealed that the productive country is Spain, with 27 documents and 221 total citations. Followed by the UK and USA with 19 and 17 documents, respectively. Interestingly, although the USA is in the 3rd level list, it has published the most-cited documents with 1103 total citations. The most prolific academic institution is Universidad Complutense de Madrid, with nine documents (35 citations). Emory University has published two documents with the highest total citation (566), and the average citation per item is 283 .

The most productive authors are Babiloni, F. with 4publications and 143 total citations, followed by Kong, W with four documents and 124 citations. Although Vecchiato, $\mathrm{G}$ in the 8th level in the list, he published the third-highest citation documents with 118 citations. Interestingly, Swiss journals dominated the publication in neuromarketing with 44 documents and with 280 total citations. Frontiers in Psychology is the most productive journal with 17 documents and 3.5 CiteScore. Article title "Neuromarketing: The hope and hype of neuroimaging in business" is the most cited article with 426 citations, which published by Ariely \& Berns (2010), followed by "From neural responses to population behaviour: neural focus group predicts population-level media effects" with the second-highest citation (167 citations) that was published by Falk et al (2012). The highest link between the two references 
MANAGEMENT SCIENCES

Vol. 11, No. 3, 2021, E-ISSN: 2225-8329 @ 2021 HRMARS

was between Ariely \& Berns (2010); Berns \& Moore (2012) with 13 links. Therefore, we encourage scholars and researchers to inspect more the neuromarketing subject and its techniques from emerging countries.

\section{Conclusions}

Marketing studies tried to understand consumers' behaviour by using several methods such as qualitative and quantitative techniques. But at the beginning of the 21st century, marketing research techniques have expanded by using new methods/techniques such as FMRI and EEG to understand better consumers' behaviour and emotional and cognitive processes toward marketing stimuli. Therefore, key players in neuromarketing have been increased; additionally, the growth of publications has risen remarkably from a document in 2008 to more than 140 documents in August 2021. The recent paper provides comprehensive information about global trends of neuromarketing domain such as the leading countries, institutions, authors, and journals-additionally, the number of documents and citations of selected documents for this study. We found that Spain is the most productive country with 27 publications, and the most productive institution was Universidad Complutense de Madrid with nine documents. In addition, Babiloni $F$. is the most prolific author with four publications and 143 citations. Interestingly, although Frontiers in Psychology is the most productive journal with 17 publications, the Journal of Economic Psychology has the highest average citation per item. Ariely and Berns (2010) have published the most cited paper with 426 citations.

This study attempted to minimise drawbacks in the methodology, but there are still limitations that provide future academic studies opportunities. For example, this study concentrates on publications that have been published in the English language in the neuromarketing domain, such as technical and reviews papers and overlooked books, chapter books, and so forth. Therefore, this study is not free of biases. For future works, we encourage scholars from emerging countries to contribute publications in the neuromarketing domain. Researchers and practitioners need to design and use the appropriate tool for their study to get high-accuracy outcomes. We believe that our research will provide a comprehensive overview of global trends in the neuromarketing domain.

\section{Corresponding Author}

Ahmed H. Alsharif

Azman Hashim International Business School (AHIBS) Universiti Teknologi Malaysia (UTM), Skudai, Johor 81310, Malaysia

Email: ahmedalsharif07@gmail.com

\section{References}

Abbas, A. F., Jusoh, A., Mas'od, A., \& Ali, J. (2020). Bibliometric analysis of global research trends on electronic word of mouth using Scopus database. Journal of Critical Reviews, 7(16), 405-412. DOI:https://doi.org/10.31838/jcr.07.16.49

Ali, J., Jusoh, A., Abbas, A. F., \& Nor, K. M. (2021a). Global trends of service quality in healthcare: A bibliometric analysis of scopus database. Journal of Contemporary Issues in Business and Government, 27(1), 2917-2930.

Ali, J., Jusoh, A., Idris, N., Abbas, A. F., \& Alsharif, A. H. (2021b). Everything is Going Electronic, so do Services and Service Quality: Bibliometric Analysis of E-Services and E-Service 
Quality. International Journal of Interactive Mobile Technologies, 15(18), 148-166. DOI:https://doi.org/10.3991/ijim.v15i18.24519

Ali, J., Jusoh, A., Idris, N., Abbas, A. F., \& Alsharif, A. H. (2021c). Nine Years of Mobile Healthcare Research: A Bibliometric Analysis. International Journal of Online \& Biomedical Engineering, 17(10).

Alsharif, A. H., Md Salleh, N. Z., Baharun, R., \& Rami Hashem E, A. (2021a). Neuromarketing research in the last five years: a bibliometric analysis. Cogent Business \& Management, 8(1), 1978620. DOI:https://doi.org/10.1080/23311975.2021.1978620

Alsharif, A. H., Salleh, N. Z. M., \& Baharun, R. (2020a). Research trends of neuromarketing: A bibliometric analysis. Journal of Theoretical and Applied Information Technology, 98(15), 2948-2962.

Alsharif, A. H., Salleh, N. Z. M., \& Baharun, R. (2021a). The neural correlates of emotion in decision-making. International Journal of Academic Research in Business and Social Sciences, 11(7), 64-77. DOI:https://doi.org/10.6007/ijarbss/v11-i7/10075

Alsharif, A. H., Salleh, N. Z. M., \& Baharun, R. (2021b). Neuromarketing: Marketing research in the new millennium. Neuroscience Research Notes, 4(3), 27-35.

DOI:https://doi.org/10.31117/neuroscirn.v4i3.79

Alsharif, A. H., Salleh, N. Z. M., \& Baharun, R. (2021b). Neuromarketing: The popularity of the brain-imaging and physiological tools. Neuroscience Research Notes, 3(5), 13-22. DOI:https://doi.org/10.31117/neuroscirn.v3i5.80

Alsharif, A. H., Salleh, N. Z. M., \& Baharun, R. (2021c). To better understand the role of emotional processes in decision-making. International Journal of Academic Research in Economics and Management Sciences, 10(2), 49-67.

DOI:https://doi.org/10.6007/ijarems/v10-i2/9883

Alsharif, A. H., Salleh, N. Z. M., Baharun, R., Alharthi, R. H. E., Mansor, A. A., Ali, J., \& Abbas, A. F. (2021d). Neuroimaging techniques in advertising research: Main applications, development, and brain regions and processes. Sustainability, 13(11), 6488-6513. DOI:https://doi.org/10.3390/su13116488

Alsharif, A. H., Salleh, N. Z. M., Baharun, R., \& Effandi, Y. M. (2021e). Consumer behaviour through neuromarketing approach. Journal of Contemporary Issues in Business and Government, 27(3), 344-354. DOI:https://doi.org/10.47750/cibg.2021.27.03.048

Alsharif, A. H., Salleh, N. Z. M., Baharun, R., \& Safaei, M. (2020b). Neuromarketing approach: An overview and future research directions. Journal of Theoretical and Applied Information Technology, 98(7), 991-1001.

Ariely, D., \& Berns, G. S. (2010). Neuromarketing: The hope and hype of neuroimaging in business. Nature Reviews Neuroscience, 11(4), 284-292.

DOI:https://doi.org/10.1038/nrn2795

Baker, H. K., Pandey, N., Kumar, S., \& Haldar, A. (2020). A bibliometric analysis of board diversity: Current status, development, and future research directions. Journal of Business Research, 108(2020), 232-246.

DOI:https://doi.org/10.1016/j.jbusres.2019.11.025

Balconi, M., Stumpo, B., \& Leanza, F. (2014). Advertising, brand and neuromarketing or how consumer brain works. Neuropsychological Trends, 16(16), 15-21.

DOI:https://doi.org/10.7358/neur-2014-016-balc

Berns, G. S., \& Moore, S. E. (2012). A neural predictor of cultural popularity. Journal of Consumer Psychology, 22(1), 154-160.

DOI:https://doi.org/10.1016/j.jcps.2011.05.001 
MANAGEMENT SCIENCES

Vol. 11, No. 3, 2021, E-ISSN: 2225-8329 ๔ 2021 HRMARS

Block, J. H., \& Fisch, C. (2020). Eight tips and questions for your bibliographic study in business and management research. Management Review Quarterly, 70(3), 307-312. DOI:https://doi.org/10.1007/s11301-020-00188-4

Bosshard, S. S., Bourke, J. D., Kunaharan, S., Koller, M., \& Walla, P. (2016). Established liked versus disliked brands: Brain activity, implicit associations and explicit responses. Cogent Psychology, 3(1), 1-16. DOI:https://doi.org/10.1080/23311908.2016.1176691

Breiter, H. C., Block, M., Blood, A. J., Calder, B., Chamberlain, L., Lee, N., . . Schultz, D. (2015). Redefining neuromarketing as an integrated science of influence. Frontiers in Human Neuroscience, 8(2), 1-7. DOI:https://doi.org/10.3389/fnhum.2014.01073

Bruce, A. S., Bruce, J. M., Black, W. R., Lepping, R. J., Henry, J. M., Cherry, J. B. C., . . Brooks, W. M. (2014). Branding and a child's brain: An fMRI study of neural responses to logos. Social Cognitive and Affective Neuroscience, 9(1), 118-122. DOI:https://doi.org/10.1093/scan/nss109

Cherubino, P., Martinez-Levy, A. C., Caratu, M., Cartocci, G., Di Flumeri, G., Modica, E., . . . Trettel, A. (2019). Consumer behaviour through the eyes of neurophysiological measures: State of the art and future trends. Computational Intelligence and Neuroscience, 3(2), 01-41. DOI:https://doi.org/10.1155/2019/1976847

Comerio, N., \& Strozzi, F. (2019). Tourism and its economic impact: A literature review using bibliometric tools. Tourism economics, 25(4), 109-131.

DOI:https://doi.org/10.1177/1354816618793762

Constantinescu, M., Orindaru, A., Pachitanu, A., Rosca, L., Caescu, S.-C., \& Orzan, M. C. (2019). Attitude evaluation on using the neuromarketing approach in social media: Matching company's purposes and consumer's benefits for sustainable business growth. Sustainability, 11(24), 7094. DOI:https://doi.org/10.3390/su11247094

Cuesta-Cambra, U., Niño-González, J.-I., \& Rodríguez-Terceño, J. (2017). The cognitive processing of an educational app with EEG and eye tracking. Media Education Research Journal, 25(52), 41-50. DOI:https://doi.org/10.3916/c52-2017-04

Falk, E. B., Berkman, E. T., \& Lieberman, M. D. (2012). From neural responses to population behavior: Neural focus group predicts population-level media effects. Psychological science, 23(5), 439-445. DOl:https://doi.org/10.1177/0956797611434964

Guixeres, J., Bigné, E., Ausín Azofra, J. M., Alcañiz Raya, M., Colomer Granero, A., Fuentes Hurtado, F., \& Naranjo Ornedo, V. (2017). Consumer neuroscience-based metrics predict recall, liking and viewing rates in online advertising. Frontiers in Psychology, 8(3), 1808. DOI:https://doi.org/10.3389/fpsyg.2017.01808

Harris, J., Ciorciari, J., \& Gountas, J. (2018). Consumer neuroscience for marketing researchers. Journal of Consumer Behaviour, 17(3), 239-252.

DOI:https://doi.org/10.1002/cb.1710

Harris, J., Ciorciari, J., \& Gountas, J. (2019). Consumer neuroscience and digital/social media health/social cause advertisement effectiveness. Behavioral Sciences, 9(4), 25.

DOI:https://doi.org/10.3390/bs9040042

Isabella, G., Mazzon, J. A., \& Dimoka, A. (2015). Culture differences, difficulties, and challenges of the neurophysiological methods in marketing research. Journal of International Consumer Marketing, 27(5), 346-363.

DOI:https://doi.org/10.1080/08961530.2015.1038761

Kumar, S., Sureka, R., \& Colombage, S. (2019). Capital structure of SMEs: A systematic literature review and bibliometric analysis. Management Review Quarterly, 4(2), 1-31. DOI:https://doi.org/10.1007/s11301-019-00175-4 
MANAGEMENT SCIENCES

Vol. 11, No. 3, 2021, E-ISSN: 2225-8329 ๔ 2021 HRMARS

Lin, Y. P., Yang, Y. H., \& Jung, T. P. (2014). Fusion of electroencephalographic dynamics and musical contents for estimating emotional responses in music listening. Frontiers in Neuroscience, 8. DOI:https://doi.org/10.3389/fnins.2014.00094

Minguillon, J., Lopez-Gordo, M. A., Renedo-Criado, D. A., Sanchez-Carrion, M. J., \& Pelayo, F. (2017). Blue lighting accelerates post-stress relaxation: Results of a preliminary study. PloS one, 12(10), e0186399. DOI:https://doi.org/10.1371/journal.pone.0186399

Moher, D., Shamseer, L., Clarke, M., Ghersi, D., Liberati, A., Petticrew, M., . . Stewart, L. A. (2015). Preferred reporting items for systematic review and meta-analysis protocols (PRISMA-P) 2015 statement. Systematic reviews, 4(1), 1-9.

DOI:https://doi.org/10.1186/2046-4053-4-1

Morris, J. D., Klahr, N. J., Shen, F., Villegas, J., Wright, P., He, G. J., \& Li, Y. J. (2009). Mapping a multidimensional emotion in response to television commercials. Human Brain Mapping, 30(3), 789-796. DOI:https://doi.org/10.1002/hbm.20544

Ravikumar, S., Agrahari, A., \& Singh, S. N. (2015). Mapping the intellectual structure of scientometrics: A co-word analysis of the journal Scientometrics (2005-2010). Scientometrics, 102(1), 929-955.

Riedl, R., Banker, R. D., Benbasat, I., Davis, F. D., Dennis, A. R., Dimoka, A., . . Kenning, P. (2010). On the foundations of NeurolS: Reflections on the Gmunden Retreat 2009. Communications of the Association for Information Systems, 27(1), 15. DOI:https://doi.org/10.17705/1cais.02715

Smidts, A. (2002). Kijken in het brein: Over de mogelijkheden van neuromarketing. Netherland. Erasmus Research Institute of Management.

Soleymani, M., Chanel, G., Kierkels, J. J., \& Pun, T. (2009). Affective characterization of movie scenes based on content analysis and physiological changes. International Journal of Semantic Computing, 3(02), 235-254.

DOI:https://doi.org/10.1142/s1793351×09000744

Solnais, C., Andreu-Perez, J., Sánchez-Fernández, J., \& Andréu-Abela, J. (2013). The contribution of neuroscience to consumer research: A conceptual framework and empirical review. Journal of Economic Psychology, 36(3), 68-81. DOI:https://doi.org/10.1016/j.joep.2013.02.011

Stallen, M., Smidts, A., Rijpkema, M., Smit, G., Klucharev, V., \& Fernandez, G. (2010). Celebrities and shoes on the female brain: The neural correlates of product evaluation in the context of fame. Journal of Economic Psychology, 31(5), 802-811. DOI:https://doi.org/10.1016/j.joep.2010.03.006

Stanton, S., Armstrong, W., \& Huettel, S. (2017). Neuromarketing: Ethical implications of its use and potential misuse. Journal of Business Ethics, 144(4), 799-811. DOI:https://doi.org/10.1007/s10551-016-3059-0

Van Eck, N., \& Waltman, L. (2013). Manual for VOSviewer version 1.5. 4. Universiteit Leiden and Erasmus Universiteit Rotterdam, 1(1), 1-53.

Vecchiato, G., Astolfi, L., Fallani, F. D., Toppi, J., Aloise, F., Bez, F., Babiloni, F. (2011). On the use of EEG or MEG brain imaging tools in neuromarketing research. Computational Intelligence and Neuroscience, 2011(3), 1-12.

DOI:https://doi.org/10.1155/2011/643489

Venkatraman, V., Dimoka, A., Pavlou, P. A., Vo, K., Hampton, W., Bollinger, B., .. Winer, R. S. (2015). Predicting advertising success beyond traditional measures: New insights from neurophysiological methods and market response modeling. Journal of Marketing Research, 52(4), 436-452. DOI:https://doi.org/10.2139/ssrn.2498095 
INTERNATIONAL JOURNAL OF ACADEMIC RESEARCH IN ACCOUNTING, FINANCE AND MANAGEMENT SCIENCES

Vol. 11, No. 3, 2021, E-ISSN: 2225-8329 ๔ 2021 HRMARS

Walvis, T. H. (2008). Three laws of branding: Neuroscientific foundations of effective brand building. Journal of Brand Management, 16(3), 176-194.

DOI:https://doi.org/10.1057/palgrave.bm.2550139

Wang, M., \& Chai, L. (2018). Three new bibliometric indicators/approaches derived from keyword analysis. Scientometrics, 116(3), 721-750.

DOI:https://doi.org/10.1007/s11192-018-2768-9 